\title{
Critical Thinking Ability of German Literature Departement's Stu- dents of Universitas Negeri Malang in Writing Thesis
}

\author{
Ferina Aulia Lestari $^{(1)}$, Primardiana Hermilia Wijayati ${ }^{(2)}$ \\ Universitas Negeri Malang, Indonesia \\ E-mail: (1)ferinaulialestari@gmail.com, ${ }^{(2)}$ primardiana.hermilia.fs@um.ac.id2
}

Received: 21 June 2021; Revised: 20 August 2021; Accepted: 11 November 2021

\begin{abstract}
This article is a research result which aims to uncover the critical thinking skills of students of German Literature Department, Universitas Negeri Malang (UM) in writing thesis. The method used is qualitative content analysis with a coding sheet as an instrument. The data is taken from some chapters in German thesis, to be particular the background, the discussion, and the conclusion sections. The collected data is reduced, grouped, then the emerging patterns are analyzed and conclusions are drawn. Students' critical thinking skills in writing thesis were analyzed from four cognitive abilities (analysis, synthesis, evaluation, and argumentation) and nine cognitive standards (clarity, clarity, accuracy, precision, relevance, depth, breadth, logic, significance, and fairness). The results showed that students were good at analyzing, synthesizing, and evaluating. However, from the argumentation aspect, students' critical ability is still considered weak, because they produced errors in ethos, logos, and pathos arguments, still made incomplete structures, and did not meet the criteria for critical thinking/cognitive standards of breadth and depth. To maximize critical thinking skill the students have to keep up their ability to analyze, synthesize, and evaluate. They also need to improve their argumentation skill, by learning the concept of fallacies, good arguments, and have the habit of reading and writing.
\end{abstract}

Keywords: critical thinking; college student; write; thesis

\section{Introduction}

Digitalization and the development of information technology have led to massive information dissemination and changes and challenges in various aspects of life (Rafzan et al., 2020). In order to survive in a dynamic global environment, students should have 21st century skills called $5 \mathrm{C}$ and one of the most important of those skills is critical thinking (Pratiwi S \& Rusman, 2018). According to Ardiyani et al., (2020) critical thinking is also one of the abilities that should be possessed by graduates who are ready to work. This ability is defined as the ability to think clearly and rationally concerning a problem or situation and then find the best solution (Yosintha \& Arochman, 2020).

Critical thinking skills can be seen from speaking and writing skills (Ardiyani et al., 2019) and according to Wijayati et al., (2020) writing is a difficult skill, compared to speaking, reading and listening. Various research publications reveal that critical thinking skills have a major influence on the ability to write scientific papers (Argiandini, 2020; Dong $\&$ Yue, 2015) because the process requires the ability to analyze, evaluate, synthesize and compose arguments, as well as rectify thoughts and arguments (Gottschlich \& Müller, 2019). In this study, two conceptual frameworks were used as indicators of students' critical thinking skills in writing thesis. First, there are four aspects of critical thinking, i.e. analysis, synthesis, evaluation, and argumentation. The second is intellectual standards, i.e. clarity, accuracy, precision, relevance, depth, breadth, logic, significance, and fairness.

Analytical skills are used when deciding a 
topic to raise and when introducing ideas and points to be discussed in writing (Lin, 2018). Analyzing means interpreting information, so that one can determine meaning and look for relevant evidence to strengthen an argument (Reynders et al., 2020). A person is said to be able to analyze if he or she can identify the relationship between statements, questions, concepts, descriptions and models, and diligently seeks relevant information (Amin et al., 2017).

The ability to evaluate in writing a thesis is used to assess the relevance of information, evidence, data, or theories applied to support arguments or statements, both in the background and discussion of research results. The ability to evaluate is also used to assess the credibility of the source of information, whether it is quite valid, trustworthy and has a good reputation. In addition, the availability of abundant sources of information on the internet creates a tendency for plagiarism (Rodhiya et al., 2020) and will certainly not meet the criteria for critical thinking, i.e. justice and honesty. Examples of credible sources are international journal articles, government publications or websites, or books from experts in the relevant field.

Synthesis means integrating and linking diverse information to support arguments or to draw conclusions. In the process of synthesizing, a person combines new information or knowledge with previous knowledge (Reynders et al., 2020). This ability is used to compile discussions that meet the criteria for critical thinking in all thesis chapters. The ability to synthesize also plays a role in formulating reasons/ evidence into good and correct sentences to support arguments, so that readers can understand clearly and there is no distortion of meaning.

An important element of critical thinking is argumentation. Argumentation is a process of explaining the relevant reasons why someone should accept or agree to something. An argument is usually persuasive and consists of a premise in the form of reasons/evidence that supports the argument and a statement of conclusions. According to (Widyastuti, 2018) there are four important elements to evaluate writing and identify critical thinking skills, i.e. arguments, evidence, acknowledgment of other points of view, and errors in arguments/ fallacies. Arguments can be identified through the premise and conclusion indicators based on the words used.

Furthermore, the intellectual standards of the critical thinking model of Yanning, (2017) are used to evaluate the statements, arguments, and supporting reasons. The criteria are clarity, accuracy, precision, relevance, depth, breadth, logic, significance, and fairness.

According to research by Tahira \& Haider (2019), Asian/non-Western students tend to have difficulty implementing critical thinking in the writing process. One of them is in writing a cohesive, coherent, and analytical discussion as they explain too much research data, without trying to analyze, interpret and connect the results of their research with existing theories. The reason is that the idea of self-expression, as well as a lack of capacity and confidence to express thoughts, is still uncommon. The non-Western cultural factors are collectivity and hierarchical tendencies.

Several studies related to critical thinking in writing have been carried out in several places, including at University of Surabaya (Pramonojati et al., 2020) which examines critical thinking skills in student research backgrounds. Furthermore, research conducted in China and England examined students' critical thinking in terms of positioning theory ( $\mathrm{Pu} \&$ Evans, 2019). Related research was also conducted at STKIP Muhammadiyah Bogor to explore the students' critical thinking in argumentative writing (Srinawati \& Alwi, 2020). The aforementioned researches conducted to analyze student's critical thinking in thesis that written in English or Bahasa Indonesia. The research on critical thinking skills in writing German thesis has never been studied especially at Universitas Negeri Malang, Department of German Literature.

Therefore, the purpose of this study was to uncover the critical thinking ability of German Literature students at UM in writing a thesis, especially in the background, the discussion, and the conclusions, seen from the indicators of the ability to analyze, synthesize, evaluate, and argue, as well as fulfill the criteria for critical thinking in writing i.e. clarity, accuracy, precision, relevance, depth, breadth, logic, significance, and fairness. Through this research the student's critical thinking skill are conveyed, thus they can maximize their critical thinking for academic and/or daily life purpose.

\section{Materials and Method}

This study uses qualitative research methods with content analysis as a data analysis technique. The data source of this research is the thesis of the students of the Department of German 
Table 1. coding sheet of critical thinking

\begin{tabular}{|l|l|l|l|}
\hline No & Code of & Sentences & $\begin{array}{l}\text { Code of CT cri- } \\
\text { teria and aspect }\end{array}$ \\
\hline 1 & H.DA.2 & & $\begin{array}{l}\sqrt{ } \\
\mathrm{X}:\end{array}$ \\
\hline$\cdots$ & & & \\
\hline
\end{tabular}

Table 2. code of critical thinking aspect

\begin{tabular}{|c|c|c|}
\hline $\begin{array}{l}\text { Critical } \\
\text { thinking } \\
\text { aspect }\end{array}$ & Indicator & $\begin{array}{l}\text { cod } \\
\text { e }\end{array}$ \\
\hline \multirow{4}{*}{$\begin{array}{l}\text { Analysis + } \\
\text { synthesis }\end{array}$} & Category & A.1 \\
\hline & Comparison & A. 2 \\
\hline & Cause-effect & A.3 \\
\hline & Chronology & A. 4 \\
\hline Evaluation & Assess idea/statement & $\mathrm{B}$ \\
\hline $\begin{array}{l}\text { Argumentatio } \\
\mathrm{n}\end{array}$ & Argument & $\mathrm{C}$ \\
\hline
\end{tabular}

Table 3. code of criteria for critical thinking

\begin{tabular}{|c|c|c|}
\hline Criteria & Code & Criteria \\
\hline Clarity & E.1 & Breadth \\
\hline Accuracy & E.2 & Logic \\
\hline Precision & E.3 & Signifi- \\
\hline Rele- & E.4 & Fairness \\
\hline \multirow[t]{12}{*}{ Depth } & E.5 & \\
\hline & \multicolumn{2}{|c|}{$\begin{array}{l}\text { collecting and } \\
\text { understanding the thesis }\end{array}$} \\
\hline & & 1 \\
\hline & \multicolumn{2}{|c|}{ marking the sentences } \\
\hline & & L \\
\hline & \multicolumn{2}{|c|}{ analyzing and coding } \\
\hline & & 7 \\
\hline & \multicolumn{2}{|c|}{ organizing the data } \\
\hline & & 7 \\
\hline & \multicolumn{2}{|c|}{ making conlusion } \\
\hline & \multicolumn{2}{|c|}{ 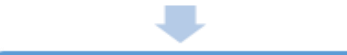 } \\
\hline & \multicolumn{2}{|c|}{ validating the data } \\
\hline
\end{tabular}

Figure 1. Flowchart of data collection
Literature at UM which is written in German. The part of the thesis that is analyzed as research data is a copy of the thesis on the background, the discussion, and the conclusion.

\section{Coding sheet instrument}

The instrument used is a coding sheet to find out two things in a student's thesis, the first is the use of four critical thinking aspects, the second is the fulfillment of critical thinking criteria in writing. This coding sheet was prepared in advance according to the theoretical basis of the research, before the data collection stage.

Figure 1 show The first stage in data collection is to determine and collect the thesis to be analyzed, then understand the thesis holistically. After that, mark the sentences in the background, the discussion and the conclusion chapters that show four aspects of critical thinking. Sentences or paragraphs that have been marked are then analyzed and coded according to the coding guidelines that have been made.

The data that has been collected will be reduced, simplified, and classified which parts are relevant and which are not, then categorized and arranged systematically to facilitate understanding and drawing conclusions. Next, conclusions are drawn, the data and patterns that appear are explained, and conclusions are drawn, to answer the problem formulation. The last step is the validity test, to get valid data, the data has been systematically compiled and concluded, tested by experts, in this study the expert is the lecturer of the Department of German Literature UM.

\section{Results and Discussion}

There are nine German theses which were analyzed based on the coding sheet to determine the use of four critical thinking skills and the fulfillment of nine critical thinking criteria in student thesis. In general, there are two types of thesis that are analyzed, i.e. development research thesis and applied or phenomenon research thesis. A total of four theses are included in the type of development research thesis, while the remaining five are applied or phenomena research thesis. The thesis analyzed is a thesis written from 2016 to 2020.

The first aspect of critical thinking ability to be analyzed is the ability to analyze and synthesize. Analytical ability is the ability to identify attributes, schemas, relationships, and main ideas. For example, arranging something in categories, finding similarities and differences between two or 
Journal Of Development Research, 5 (2), November 2021, Pages 164-173

Table 4. Analysis and Synthesis Ability Data

\begin{tabular}{|c|c|c|c|c|c|c|c|c|c|c|c|c|}
\hline \multirow[t]{2}{*}{$\begin{array}{l}\text { Paragraph } \\
\text { Type }\end{array}$} & \multirow[t]{2}{*}{$\begin{array}{l}\text { Number of } \\
\text { sentences }\end{array}$} & \multicolumn{9}{|c|}{$\begin{array}{l}\text { The number of sentences that meet the criteria for } \\
\text { critical thinking * }\end{array}$} & \multicolumn{2}{|c|}{$\begin{array}{ll}\text { cohesion } & \text { and } \\
\text { coherence }\end{array}$} \\
\hline & & 1 & 2 & 3 & 4 & 5 & 6 & 7 & 8 & 9 & $\sqrt{ } * *$ & $\mathrm{X}^{*}$ \\
\hline Category & 6 & 6 & 6 & 6 & 6 & 3 & 4 & 6 & 6 & 3 & 6 & - \\
\hline Comparison & 15 & 13 & 14 & 6 & 15 & 14 & 5 & 12 & 13 & 14 & 10 & 5 \\
\hline Cause-effect & 11 & 11 & 11 & 9 & 11 & 11 & 5 & 11 & 11 & 11 & 11 & - \\
\hline Chronology & 8 & 8 & 8 & 8 & 8 & 6 & 5 & 8 & 8 & 8 & 8 & - \\
\hline
\end{tabular}

Note:

*: criteria 1-clarity, 2-accuracy, 3-precision, 4-relevance, 5-depth, 6-broadness, 7-logical, 8-significant, 9fairness

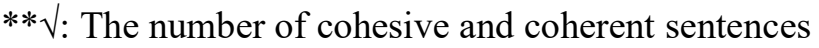

$\mathrm{X}$ : The number of sentences that are not cohesive and coherent

Table 5. Evaluation Ability Data

\begin{tabular}{|c|c|c|c|}
\hline \multirow{2}{*}{$\begin{array}{c}\text { Number of } \\
\text { evaluation } \\
\text { sentences }\end{array}$} & $\begin{array}{c}\text { Assessment criteria/standards } \\
\text { Number of sen- } \\
\text { tences listed crite- } \\
\text { ria }\end{array}$ & $\begin{array}{c}\text { The number of sen- } \\
\text { tences that are not } \\
\text { listed criteria }\end{array}$ & The words used in the evaluation paragraph \\
\hline 26 & 11 & 15 & $\begin{array}{l}\text { Beliebt; interessant/uninterssant; gut; wichtig; } \\
\text { passend; nicht genau; nicht vollständig; zu eng; } \\
\text { nicht geeignet; langweilig; relevant (favourite, } \\
\text { interesting/unattractive, good, important, appro- } \\
\text { priate, inappropriate, inaccurate, incomplete, too } \\
\text { narrow, unsuitable, boring, relevant) }\end{array}$ \\
\hline
\end{tabular}

more things, finding the cause or effect of something, and also determining the sequence of events based on their time sequence. As for the synthesis ability, it is the ability to integrate a variety of information in organizing paragraphs which can be in the form of comparison paragraphs, categories, causes and effects, and chronology. Most of the paragraphs and sentences of organizing principles found in student thesis meet the criteria of critical thinking and are cohesively and coherently arranged. In addition, only five of the forty sentences analyzed did not show cohesion and coherence. Details of the data from the analysis and synthesis aspects are shown in table 4.

In student thesis, many conjunctions are found as lexical tools to compose cohesive and coherent paragraphs, including: danach, und, dass, aber, weil, oder, sondern, dann (hereinafter, and, that, but, because, but, then). The conjunctions und and weil are the most common. In addition to conjunctions, repetition of key words or main ideas is also a lexical tool in a cohesive and coherent paragraph, as well as the use of pronouns, both personal and object pronouns.

In the synthesis process, it is not only from the aspect of coherence and paragraph cohesion that integrates the information that needs to be considered, but also from the aspects of grammar, diction and sentence structure. In the student's thesis, one error was found in the use of the word, which should have been the verb "sprechen" (to speak) instead it used the word "sprachen".

In the aspect of evaluation ability, students demonstrate the ability to assess an idea or statement based on certain criteria or standards. This standard is built from the students themselves, both from their experiences, data, facts, knowledge and beliefs, but not all criteria or standards are clearly stated in paragraphs. Details of data from the aspect of evaluation ability are shown in table 5 .

The following example, Basierend auf die Kriterienliste von Fräßdorf werden die Aspectte im Lehrwerk Deutsch Macht Spaß” angeboten. Ingesamt ist das Lehrwerk Deutsch Macht Spaß“” 
Table 6. Argumentation Ability Data

\begin{tabular}{|c|c|c|c|c|c|c|c|c|c|c|c|c|}
\hline \multirow{2}{*}{$\begin{array}{c}\text { Number of } \\
\text { argumentatio } \\
\text { n paragraphs }\end{array}$} & \multicolumn{6}{|c|}{ The number of paragraphs that meet the criteria for critical } & \multicolumn{2}{|c|}{$\begin{array}{c}\text { Number of sentences with } \\
\text { errors }\end{array}$} \\
\cline { 2 - 14 } & $\mathbf{1}$ & $\mathbf{2}$ & $\mathbf{3}$ & $\mathbf{4}$ & $\mathbf{5}$ & $\mathbf{6}$ & $\mathbf{7}$ & $\mathbf{8}$ & $\mathbf{9}$ & $\mathbf{L o g o s}$ & Ethos & Pathos \\
\hline a27 & 27 & 27 & 17 & 27 & 16 & 5 & 22 & 27 & 9 & 5 & 17 & 1 \\
\hline
\end{tabular}

Note:

*: criteria 1-clarity, 2-accuracy, 3-precision, 4-relevance, 5-depth, 6-broadness, 7-logical, 8-significant, 9-fairness

Table 7. Example argument with error

\begin{tabular}{|c|c|c|}
\hline Error & Example argument & Comment \\
\hline Logos & $\begin{array}{l}\text { Im Kurs Konversation I benutzt der/die Dozent/in oft das } \\
\text { Rollenspiel. Das Rollenspiel kann soziales Verhalten der } \\
\text { Lernenden verbessern. Die StudentInnen, die den Kurs } \\
\text { Konversation I besucht haben, haben gesagt, dass das } \\
\text { Rollenspiel eine gute Methode ist, aber als sie das } \\
\text { Rollenspiel gemacht bzw. gespielt haben, waren sie oft } \\
\text { nervös, hatten kein Selbstvertrauen, und haben sich } \\
\text { geschämt. (In the Konversation I class, the lecturer often } \\
\text { uses the role-playing method. Role playing can improve the } \\
\text { social behavior of learners. Students who took the } \\
\text { Conversation I class said that role playing is a good method, } \\
\text { but when they play, they are often nervous, insecure and } \\
\text { shy..) }\end{array}$ & $\begin{array}{l}\text { The reason that underlies the argument that } \\
\text { Rollenspiel is often used by lecturers in the } \\
\text { Konversation I class is illogical and irrele- } \\
\text { vant to the argument "Das Rollenspiel } \\
\text { kann ... verbessern", because that reason is } \\
\text { not in the form of data, facts, or expert } \\
\text { statements, and there are no reliable } \\
\text { sources. declare the validity of the state- } \\
\text { ment. }\end{array}$ \\
\hline Ethos & $\begin{array}{l}\text { Ursprünglich waren nur die Lehrer die einzige Lernquelle } \\
\text { zum Lernen, aber jetzt benötigt es verschiedene } \\
\text { Lernquellen. Also sollen die Schüler versuchen, diese } \\
\text { Lernquellen möglichst so gut zu nutzen. (Initially, the } \\
\text { teacher was the only source of learning in learning, but now } \\
\text { various kinds of learning resources are needed. So students } \\
\text { should try to make the most of these learning resources.) }\end{array}$ & $\begin{array}{l}\text { The credibility of the reasons that support } \\
\text { the argument is questionable, because there } \\
\text { is no source information, and whether the } \\
\text { basis for these reasons comes from a valid } \\
\text { and reliable source. }\end{array}$ \\
\hline Pathos & $\begin{array}{l}\text { Im Kurs Konversation I benutzt der/die Dozent/in auch } \\
\text { einige Lernmedien, jedoch sind sie manchmal uninteressant, } \\
\text { zum Beispiel Power Point-Präsentation. Der/die Dozent/in } \\
\text { präsentiert häufig mit Power Point-Präsentation, deswegen } \\
\text { langweilen sich die StudentInnen und geben sie ihre } \\
\text { Aufmerksamkeit nicht. Die Variation der Lernmedien im } \\
\text { Kurs Konversation I ist deshalb notwendig. (In the } \\
\text { Konversation I class, the lecturer also uses some learning } \\
\text { media, but sometimes it's boring, for example Power-Point } \\
\text { Presentations. Lecturers often use Power-Point } \\
\text { presentations, so students feel bored and don't pay attention. } \\
\text { Therefore, variations of learning media in the Conversation } \\
\text { I class are needed) }\end{array}$ & 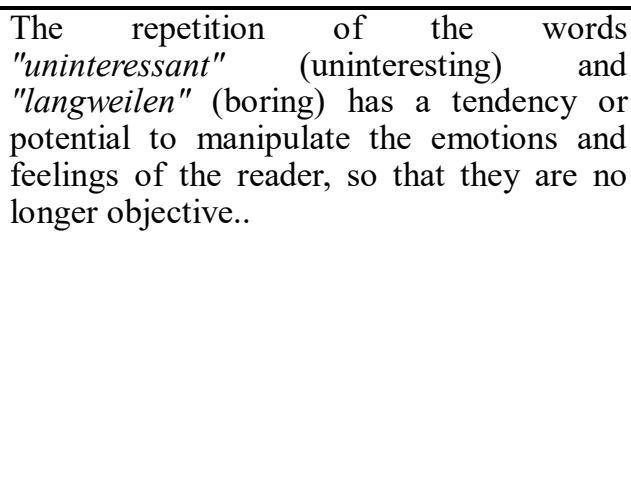 \\
\hline
\end{tabular}


für die Aspect Hören, Sprechen, Lesen, Schreiben, Wortschatz, Grammatik, Authentizität gut (Based on Fräßdorf's list of criteria, aspects of Deutsch Macht Spa teaching materials are presented. In general, Deutsch Macht Spa teaching materials are presented. both for aspects of listening, speaking, reading, writing, vocabulary, grammar, and authenticity) indicated that students made an assessment based on their knowledge of the Fräßdorf criteria, and the basis for the assessment was clearly stated in the sentence. Another example that does not clearly state the basis for the assessment is Ein dreidimensionales Medium wie die Handpuppe ist nun beliebt (a three-dimensional medium such as a hand puppet is now a favourite). In this sentence, three-dimensional media, such as Handpuppe (hand puppet) is rated as the favourite, but the basis for this assessment is not clearly stated in the sentence.

Not only evaluating ideas or statements, evaluation ability is also used when determining the sources to be used in compiling the thesis, because in determining the sources credibility, validity and reputation should be considered. In the following example, students demonstrate the ability to evaluate sources well. Android wurde im Rahmen dieser Forschung und Entwicklung als das mobile Betriebssystem genutzt, weil Android das am meisten verwendete Betriebssystem in Indonesia ist (Statista, 2019) (In this study, android was used as a mobile operating system, because android is the most widely used operating system in Indonesia). Indonesia). The sources used are trusted sites that present the latest statistical data and facts, the year of citation can also be said to be up-to-date.

The most important ability in critical thinking is argumentation. In general, arguments have two aspects, i.e. evidence/reasons and conclusions. There are two types of arguments, i.e. inductive and deductive. Inductive arguments are mostly found in student thesis. An inductive argument means an argument whose supporting evidence does not guarantee the accuracy of the conclusion of an argument, while a deductive argument means that the evidence or reasons for an argument, as long as the evidence is true, guarantees the accuracy of the conclusion of the argument. In the student's deductive argument, the evidence/reason to strengthen an argument is the data or the results of calculations, so as long as the results of the calculations are correct, the conclusion of the argument can be verified as well.

In their thesis, students have stated their argument, but this argument cannot be called 'good' because most of the arguments do not meet the criteria of breadth, which acts as an important structure in an argument. In addition, almost all arguments have errors, be it ethos, logos or pathos. Most errors are ethos, related to the credibility of the sources supporting the argument, the use of language and the presence or absence of other points of view in an argument. Details of data from argumentation ability are shown in table 6 .

Table 7 shows Another important component of an argument is an appreciation of other's point of view. Most of the student arguments found in the thesis did not mention any other point of view of the problems discussed in the argument itself. For example in the following paragraph:

Viele Leute finden, dass das Rollenspiel eine interessante Methode ist, weil die Lernenden in der realitätsnahe Situation üben können. Man lernt Sprechen während des Sprechens, so dass das Rollenspiel eine passende Methode ist (many people think that role playing is an interesting method, because learners can practice in situations that are similar to reality. A person learns to speak while speaking, so role playing is a very suitable). In the paragraph above, it is stated that Rollenspiel is a suitable method, because it is an interesting method, similar to a real situation, and one can practice speaking skills when speaking, the argument only shows one view regarding a suitable method for speaking, not discussed about the method. others that may be suitable for speaking, or why other methods are not suitable for speaking practice. In addition, the reasons underlying the arguments are not supported by clear sources, so the arguments are not strong enough.

A good argument with appreciation for other views can be seen in the following example: Nach Hühner (2010:34) sollte ein Fremdsprachenunterricht mit Muttersprachlern verbunden sein. Die Lernenden knüpfen einen authentischen Kontakt mit den Muttersprachlern, damit sie nicht nur die Sprache lernen, sondern auch andere Aspectte wie die Kultur. Deshalb wäre das Distanztandem eine bessere Möglichkeit für die StudentInnen, um ihr Deutsch zu verbessern (According to Hühner foreign language learning should be connected with native speakers. Learners make authentic contact with foreign speakers, so that they learn not only the language but also other aspects such as culture. By therefore distance tandem is a better choice for 
students to improve their German language skills). In the example above, it is mentioned that Distanztandem allows students not only to learn language but also other aspects such as culture. The reasons underlying the argument come from clearly stated sources, so that the argument can be said to be strong.

\section{Discussion}

The ability of analysis and synthesis is the ability to identify attributes, schemas, relationships, and main ideas, then formulate them in cohesive and coherent organizing paragraphs in the form of comparisons, categories, causes and chronology. This is referred to Aini et al., (2021) as "critical analysis", which means combining the core meaning of a term or idea and compiling a new concept with its own sentence.

In composing a cohesive and coherent paragraph, as a characteristic of good analytical and synthesis skills, students use repetition, conjunctions, references, and pronouns. These results are in accordance with the results of research from Marto \& Jaya, (2019) which examined the background of student thesis, that repetition is more dominant lexical cohesion than the other three components such as synonyms, collocations, and superordinates, with a percentage of $93 \%$. In the German thesis for German Literature students at UM, repetition is the dominant lexical cohesion to compose a coherent paragraph, because it is the easiest means compared to other lexical cohesion, such as synonyms.

The use of conjunctions in the thesis of German Literature students at UM is also often found in coherent and cohesive paragraphs. This supports the findings of research conducted by Zainiah (2018), that the use of conjunctions as grammatical cohesion is the most common finding in descriptive paragraphs of student thesis. In addition to using conjunctions and repetitions, students also need to use other lexical cohesions, such as collocations, ellipsis, and substitutions, so that their thesis becomes more attractive and not boring.

From the aspect of evaluating students' abilities, they are also good, because in assessing a statement or idea, they use a certain standard or criteria well. These standards or criteria are built by students themselves from their own experiences, beliefs, situations and knowledge, supporting the theory from Facione (2020) that standards in assessment are built from one's experience, situation, or opinion.
In addition to assessing an idea or statement based on certain standards or criteria, evaluation skills are also used when evaluating the sources to be used in writing the thesis, whether the sources are credible, valid and have a good reputation. The abundance of information sources on the internet causes a tendency to do plagiarism (Rodhiya et al., 2020). If students do plagiarism, then their writing automatically does not meet the criteria for critical thinking, i.e. accuracy and justice. This is also closely related to the next critical thinking aspect, that is argumentation.

An argument has several components, the focal of which is being the reasons/premises and the conclusion. Another component that is no less important is the appreciation of other views of an argument. In addition, the argument should also be free from errors or also known as fallacies. In the aspect of argumentation, students are still weak, because based on research findings, in their arguments there are many errors (fallacies). The most dominant error is Ethos, this is related to the lack of credibility of the evidence to support the argument and the lack of appreciation from other points of view on an issue. The next error is $\mathrm{Pa}$ thos, which is an error related to emotion, the argument with that error has the potential to affect the emotions, feelings and perceptions of the reader. The final error is Logos. An argument can be said to have a Logos error, if the argument is not logically structured, and does not have strong evidence from data, facts, and expert statements. This supports the results of the research conducted by Sabu \& Vernandes, 2019), that the research subjects forgot to provide strong reasons or evidence to support their arguments.

The emergence of errors (fallacies) in student arguments is often associated with low knowledge and critical thinking skills. This was revealed by El Khoiri \& Widiati (2017), in their research which shows that students in their argumentative writings still produce some errors (fallacies) which can actually be avoided through simple and explicit instructions. Likewise with research conducted by Rohayati (2017) and Selpia \& Setyarini (2020), showing the same results that students' critical thinking skills become weak due to the emergence of several errors such as ethos, logos and pathos as well as weak evidence or statements in arguments. The existence of evidence/reasons that are not strong and statements containing errors (fallacies) indicate that students cannot apply HOTS to understand something.

Another problem in the student's argument is that there is no consideration or mention of 
other points of view. Appreciation of other views in an argument is an important aspect. The results of this study are in line with the results of research by (Suhartoyo, 2017) which states that the low-level students were able to defend only with a single perspective and fail to discuss other possible perspectives.

The absence of consideration or mention of other points of view on a problem in the argument automatically causes the non-fulfillment of one of the criteria for critical thinking, that is breadth. In addition to breadth, another dominant criterion that is not met is depth. Students only discuss a problem or idea only on the surface and do not mention other important factors of the problem. This shows the absence of the character of a critical thinker, who according to Facione (2020) likes to work with complexity and seek relevant information.

To improve argumentation skills, students need to have the habit of reading and writing, have knowledge related to thinking errors (fallacies), basic writing skills, especially writing scientific papers and improve higher order thinking skills (HOTS). According to Utami (2020) the way to improve HOTS abilities is to learn the concept of a concept, the stages of the learning concept, and practice thinking from abstract to concrete and vice versa.

\section{Conclusion}

In this study, the critical thinking ability of German Literature students of Universitas Negeri Malang in writing thesis was analyzed from the ability of analysis, synthesis, evaluation, and argumentation as well as from the fulfillment of critical thinking criteria. The results show that students' analytical, synthesis, and evaluation skills are good, because students can identify relationships, attributes, and schemas. Students can also formulate organizing principles in a cohesive and coherent manner. In addition, students can assess ideas and statements according to certain standards and criteria. The analyzed paragraphs of analysis, synthesis and evaluation also meet most of the criteria for critical thinking skills.

However, in terms of student arguments, it is still not good, because there are many fallacies, no consideration or mention from other points of view, and the criteria for depth and breadth of student arguments are not met yet. To maximize critical thinking skills, especially in the argumentation aspect, students need to learn the concept of fallacies, good argument structure and preparation, and have the habit of reading and writing.

\section{Suggestion}

Based on the results of this study, there are several suggestions for further research, those are 1) analyzing students' critical thinking skills in writing on several other aspects, not only analysis, synthesis, evaluation, and argumentation, for example inference, interpretation, self-regulation, explanation, clarification, and others. 2) In order to get more comprehensive research results, it is recommended for further research to add data related to students' critical thinking processes when writing thesis. Hence, it is not only assessing students' critical thinking skills from their work, but also from their thinking processes when writing.

\section{Acknowledgment}

The authors would like to thank LP2M Universitas Negeri Malang for funding this research.

\section{References}

Aini, D. N., Laksono, K., \& Ridwan, A. (2021). Indonesian-german bicultural literacy comprehension: The students' inference perspective. Journal of Language and Linguistic Studies, 17(1), 187-204. https:// doi.org/Doi: 10.52462/jlls.11

Amin, A. Mun., Duran Corebima, A., Zubaidah, S., \& Mahanal, S. (2017). The Critical Thinking Skills Profile of Preservice Biology Teachers in Animal Physiology. Proceedings of the 3rd International Conference on Education and Training (ICET 2017). 3rd International Conference on Education and Training (ICET 2017), Batu City, Indonesia. https://doi.org/10.2991/ icet-17.2017.30

Ardiyani, D. K., Wijayati, P. H., \& Afifah, L. (2019). Zum Einsatz von Critical Thinking Skils zur Erhöhung Der Sprechfertigkeit im Deutschunterricht Auf B1-Niveau. Scientific Journal of German Language, Literature and Culture, 4, 269277.

Ardiyani, D. K., Wijayati, P. H., \& Hidayat, E. (2020). Blended Learning in Teacher Profession Education (PPG) of Germany Education as The 21st Century Teacher Training Model. Journal of Development 
Research, 4(2), 125-133. https:// doi.org/10.28926/jdr.v4i2.116

Argiandini, S. R. (2020). Analisis Kemampuan Berpikir Kritis dan Kebiasaan Membaca Untuk Bekal Menulis Karya Ilmiah. https://doi.org/10.31227/osf.io/xakhm

Dong, T., \& Yue, L. (2015). A Study on Critical Thinking Assessment System of College English Writing. English Language Teaching, 8(11), $176 . \quad$ https:// doi.org/10.5539/elt.v8n11p176

El Khoiri, N., \& Widiati, U. (2017). Logical Fallacies in EFL Learners' Argumentative Writings. Dinamika Ilmu, 17(1). https:// doi.org/10.21093/di.v17i1.638

Facione, P. A., \& Llc, M. R. (2020). Critical Thinking: What It Is and Why It Counts. Critical Thinking, 33.

Gottschlich, S., \& Müller, S. (2019). Kritisches Denken im Schreibprozess. 12.

Lin, Y. (2018). Developing Critical Thinking in EFL Classes. Springer Singapore. https:// doi.org/10.1007/978-981-10-7784-5

Marto, H., \& Jaya, J. (2019). Lexical Cohesion In Background Of Research Used In Undergraduate Thesis. 3 Rd English Language and Literature International Conference (ELLiC), 3, 6.

Pramonojati, S., Carella, D. N., Fitriyah, W. D., \& Sari, I. Y. K. (2020). Students' Critical Thinking in Writing Background of Research. Proceedings of the International Conference on English Language Teaching (ICONELT 2019). International Conference on English Language Teaching (ICONELT 2019), Surabaya, Indonesia. https://doi.org/10.2991/ assehr.k.200427.061

Pratiwi S, D., \& Rusman, R. (2018). Enhancing Critical Thinking Skills in Higher Eeducation in Preparation of Insudtry 4.0: A Literature Review. Proceedings of the Third International Conerence on Education \& Reginal Development.

$\mathrm{Pu}, \mathrm{S} .$, \& Evans, M. (2019). Critical thinking in the context of Chinese postgraduate students' thesis writing: A positioning theory perspective. Language, Culture and Curriculum, 32(1), 50-62. https:// doi.org/10.1080/07908318.2018.1442473

Rafzan, Budimansyah, D., Rahmat, \& Fitriasari, S. (2020). Development of Critical Thinking Skills Through the Citizenship Education Course in the Era of Industrial Revo- lution 4.0. Proceedings of the 2nd Annual Civic Education Conference (ACEC 2019). 2nd Annual Civic Education Conference (ACEC 2019), Bandung, Indonesia. https://doi.org/10.2991/ assehr.k.200320.050

Reynders, G., Lantz, J., Ruder, S. M., Stanford, C. L., \& Cole, R. S. (2020). Rubrics to assess critical thinking and information processing in undergraduate STEM courses. International Journal of STEM Education, 7(1), 9. https://doi.org/10.1186/ s40594-020-00208-5

Rodhiya, N., Hermilia Wijayati, P., \& Bukhori, H. A. (2020). Graduate Students' Attitude Toward Plagiarism in Academic Writing. KnE Social Sciences. https:// doi.org/10.18502/kss.v4i4.6484

Rohayati, D. (2017). Students' Critical Thinking in Writing An English Exposition Text. Advances in Social Science, Education and Humanities Research (ASSEHR), 82, 5.

Sabu, V., \& Vernandes, B. (2019). An Analysis of Student's Critical Thinking Skills in Writing Argumentative Essay. Journal of Language and LIiterature, 8(2), 11.

Selpia, D., \& Setyarini, S. (2020). Students' Reasoning and Fallacies in Indonesian EFL Classroom. Proceedings of the Twelfth Conference on Applied Linguistics (CONAPLIN 2019). Twelfth Conference on Applied Linguistics (CONAPLIN 2019), Bandung, Indonesia. https:// doi.org/10.2991/assehr.k.200406.005

Srinawati, W., \& Alwi, R. (2020). Critical Thinking Ability in EFL Students' Argumentative Essay Writing: The Difficulties and the Strategies. Jurnal Serambi Ilmu, 21(2), 200-210. https://doi.org/10.32672/ si.v21i2.2194

Suhartoyo, E. (2017). The Importance of Critical Thinking Competence: An Investigation of Students' Writing Experiences. Proceeding International Seminar on Language Education and Culture, 9.

Tahira, M., \& Haider, G. (2019). The Role of Critical Thinking in Academic. International Online Journal of Primary Education, $8(1), 30$.

Utami, S. (2020). The Development of Negotiation Text Oriented to Higher Order Thinking Skills (HOTS) for Teaching Material with the Context of Life Skills in the Busi- 
ness and Industrial World. Journal of Development Research, 4(2), 97-105. https:// doi.org/10.28926/jdr.v4i2.117

Widyastuti, S. (2018). Fostering Ccritical Thinking Skills Through Argumentatve Writing. Jurnal Cakrawala Pendidikan, 2, 182-189. https://doi.org/10.21831/ cp.v37i2.20157

Wijayati, P. H., Ardiyani, D. K., Hidayat, E., \& Kharis, M. (2020). Open Educational Resources: Peluang untuk Belajar Mandiri Bahasa Jerman di Era Covid-19. Proceeding Seminar Nasional Pembelajaran Bahasa dan Sastra (Selasar) 4, 217-227.

Yanning, D. (2017). Teaching and Assessing Critical Thinking in Second Language Writing: An Infusion Approach. Chinese Journal of Applied Linguistics, 40(4). https://doi.org/10.1515/cjal-2017-0025

Yosintha, R., \& Arochman, T. (2020). Preparing English Department Students for Industry 4.0 Era through Critical Thinking Skills Development. Proceedings of the Proceedings of the 1st International Conference on Language and Language Teaching, ICLLT 2019, 12 October, Magelang, Central Java, Indonesia. Proceedings of the 1st International Conference on Language and Language Teaching, ICLLT 2019, 12 October, Magelang, Central Java, Indonesia, Magelang, Indonesia. https://doi.org/10.4108/eai.12-102019.2292229

Zainiah, N. (2018). An Analysis on Grammatical Cohesion Found in Undergraduate Theses of English Education Department Students at State Institute for Islamic Studies of Metro. State Iinstitute for Islamic Studies of Metro. 